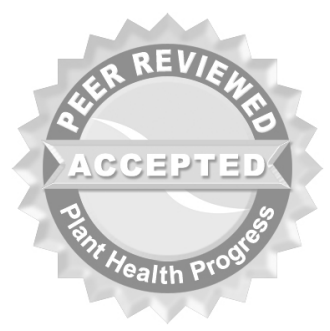

(c) 2003 Plant Management Network.

Accepted for publication 17 J uly 2003. Published 19 August 2003.

\title{
Diagnosis of Common Root Rot of Wheat and Barley
}

D. E. Mathre, R. H. Johnston, and W. E. Grey, Department of Plant Sciences and Plant Pathology, Montana State University, Bozeman 59717

Corresponding author: D. E. Mathre. upldm@montana.edu

Mathre, D. E., Johnston, R. H., and Grey, W. E. 2003. Diagnosis of common root rot of wheat and barley. Online. Plant Health Progress doi: 10.1094/PHP-2003-0819-01-DG.

\section{Disease}

Common root rot of wheat and barley.

Hosts

Triticum aestivum L (wheat) and Hordeum vulgare L. (barley).

\section{Pathogen}

Cochliobolus sativus (Ito \& Kurib.) Drechs. ex Dastur (teleomorph) and Bipolaris sorokiniana (Sacc.) Shoem. (anamorph) (=Helminthosporium sativum).

\section{Symptoms and Signs}

Initial symptoms of common root rot in either wheat or barley originate on young seedlings from inoculum carried on the seed or from infections originating from soilborne conidia near the seedling $(18,28)$. Dark brown lesions appear on the outer coleoptile tissue and/ or on the leaf base (Fig. 1). Lesions may coalesce into long areas of necrotic brown tissue. In extreme cases, the entire seedling may die. In most cases, however, the seedling will survive but growth of the developing plant may be stunted (Fig. 2).

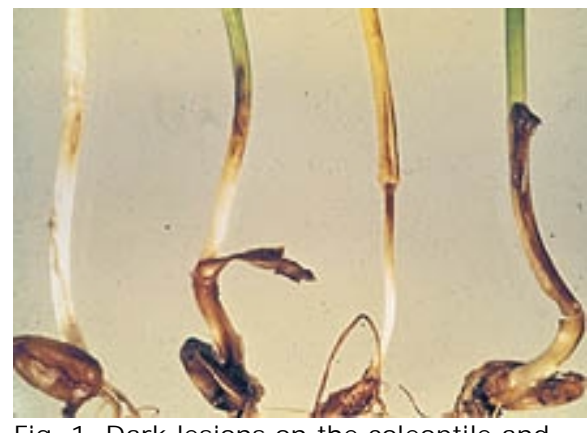

Fig. 1. Dark lesions on the coleoptile and leaf bases.

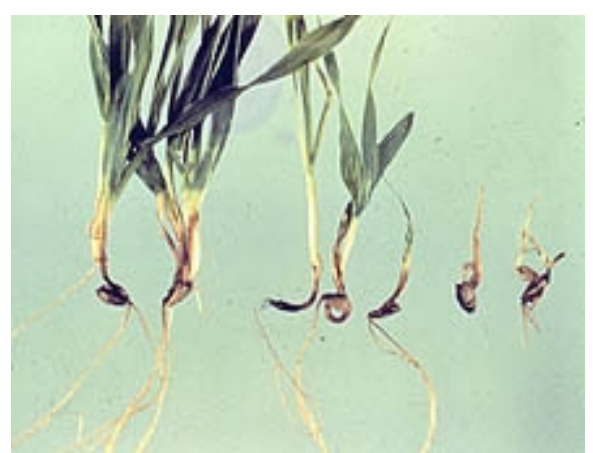

Fig. 2. Stunting of seedlings infected by the common root rot organism.

The more common symptoms are those initially seen on the subcrown internode. These are small oval brown necrotic lesions that as the plant matures may coalesce to encompass the entire subcrown internode (Figs. 3 and 4). Rarely do symptoms extend higher in the plant in contrast to the crown rot caused by various Fusaria, e.g. F. culmorum and F. graminearum (24). However, in some cases, necrosis may extend upward into the plant crown, encompassing the base of the leaves and tillers and may result in plant death prior to heading. 


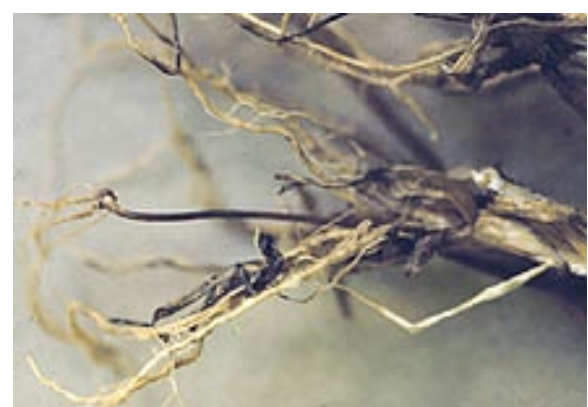

Fig. 3. Dark discoloration on infected subcrown internode of a mature plant.

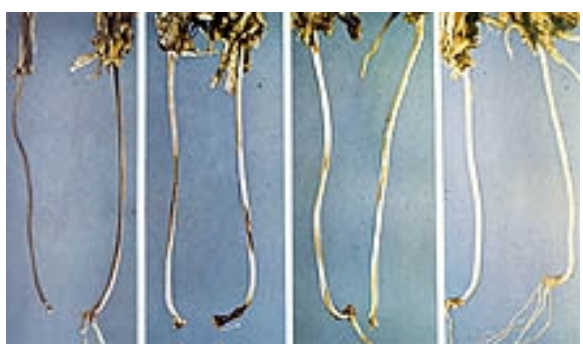

Fig. 4. Use of discoloration of the subcrown internode as a rating scale for severity of infection (right to left): Healthy, slight, moderate, severe infection.

An indirect symptom of common root rot is the decreased number of tillers that form on an infected plant as compared to the number on a healthy plant (Fig. 5) (7).

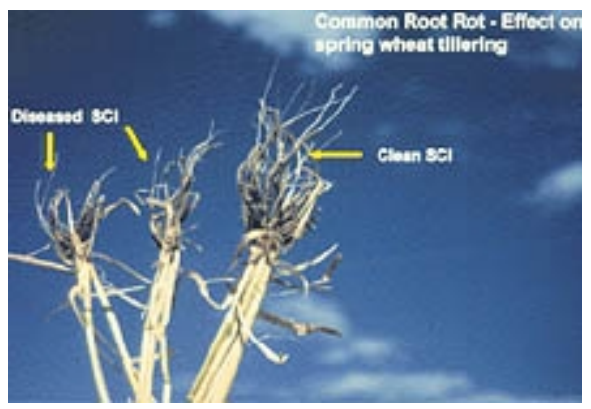

Fig. 5. Decreased number of tillers in wheat plants infected with common root rot.

Signs of common root rot are rare since the fungal pathogen does not form definite anamorphic fruiting bodies. However, production of the dark brown conidia can occasionally be found on necrotic tissue at plant maturity. Sporulation on tissue placed on various media or in a moist chamber does occur and is an aid in accurate diagnosis of the pathogen in the laboratory. The teleomorph is rarely found under natural conditions and usually does not develop in culture.

\section{Host Range}

Cochliobolus sativus is a pathogen of many grasses (at least 45 genera of grasses) as well as wheat and barley $(10,11,12)$.

\section{Geographic Distribution}

The pathogen is distributed world-wide in all of the major cereal growing regions. Within a region, it is rare to find a field that does not harbor the pathogen at some level of inoculum.

\section{Pathogen I solation}

The anamorphic stage of C. sativus is easily isolated from symptomatic tissue placed under moist conditions. Conidia form quickly and are quite evident by their characteristic dark brown oval shape with thick cross walls (Fig 6). They usually appear within a few days at room temperature. 


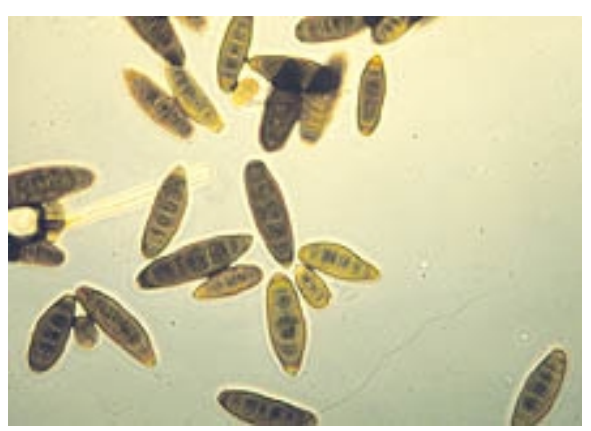

Fig. 6. Conidia of the common root rot pathogen, Cochliobolus sativus.

From tissue. To isolate the pathogen from infected tissues on various media it is best to wash the tissue well with running water from several minutes to 1 to 2 hours. It can then be plated directly onto an agar medium, but it is usually best to surface sterilize it first in $0.5 \% \mathrm{NaOCl}$ for $30 \mathrm{sec}$ to several minutes. Either touch the plant tissue briefly with clean sterile tissue paper to wick off the excess $\mathrm{NaOCl}$, or rinse it briefly in sterile water prior to placement on the medium.

Media that can be used include water agar, corn meal agar, or potato dextrose agar of varying strengths (full to $1 / 10$ strength). Other media that also work well include V-8 juice medium, Czpeck's agar, or a glucose mineral salts medium (23) (see Appendix for recipes).

If the tissue is badly rotted, with the potential for harboring mixed infections, benomyl ( 2 to $10 \mathrm{mg}$ per liter) can be added to any of the media above. Specht and Rush (22) have also used their selective medium in making isolations directly from tissue.

From soil. Various techniques and media have been used to isolate the pathogen directly from soil. C. sativus exists from one growing season to the next primarily as conidia in soil, and not as mycelium in the soil or in plant tissue. Initial work by Chinn (3) involved separation of the conidia from soil using solutions that would selectively separate the conidia from soil, e.g., use of mineral oil. However, most have found this technique to be messy and cumbersome. To eliminate this problem, several selective media have been developed that allow soil dilution platings $(6,21,22)$.

\section{Pathogen I dentification}

The anamorphic or conidial stage of C. sativus is the one normally encountered. It is characterized by the presence of olive-brown conidiophores and large brown phragmoid (cross walls only in one direction) conidia borne laterally and terminally on the conidiophore (Fig. 6). The conidia of Pyrenophora sp. can be confused with those of C. sativus. The very thick walls of $\mathrm{C}$. sativus conidia distinguish them from the very thin transparent walls of the conidia of Pyrenophora. Germination of C. sativus conidia occurs only from the polar (end) cells of the conidium.

The teleomorphic stage is an ascostroma with a dark exterior and a whitish pseudoparenchymatous interior when young. At first they are immersed in host tissue, but later are erumpent. Ascospores occur in a helical arrangement in the ascus, are more than 5 microns wide, multiseptate, hyaline to light colored. This stage of the fungus is rarely encountered.

\section{Pathogen Storage}

Cochliobolus sativus grows well on many media and can be stored short times (up to one year) as agar slants, with periodic transfer. For long-term storage, it is best to suspend the conidia in sterile $15 \%$ glycerol and store at - $70^{\circ}$ C. If such facilities are not available, the fungus can be cultured on sterile mature wheat straw that is allowed to dry slowly at room temperature after colonization. Conidia produced on the surface of the straw will remain viable for several years when the straw is stored at 15\% relative humidity or less, at either room temperature or at $4^{\circ} \mathrm{C}$. 


\section{Taxonomy}

The teleomorph of the common root rot pathogen is Cochliobolus sativus, a Loculoascomycete in the order Dothideales. It produces pseudothecia but these have not been found in nature (13). The anamorph is Bipolaris sorokiniana, previously known as Helminthosporium sativum. It produces multicelled dark colored conidia and is one of the dematiacious fungi (and is thus dark-spored) (1).

\section{Pathogenicity Tests}

Inoculum production. The inoculum which initiates infection of common root rot consists almost exclusively of conidia. These can be produced on a variety of media including V-8 agar, glucose mineral salts, or agar containing natural products such as straw, chopped barley leaves, etc. Temperatures of 21 to $25^{\circ} \mathrm{C}$ work well. Light does not seem to be crucial, though many have used various lighting regimes including natural light and artificial lighting, including UV light, to insure good sporulation. The conidia are scrapped or washed from the media and added directly to sand or soil for pathogenicity studies. Inoculum densities of 50 to 200 viable conidia per gram of soil are usually used since these levels approximate the naturally-occurring levels in field soil (8).

In some cases, the pathogen has been grown on moistened autoclaved oat kernels ( 1 part water to 2 parts kernels $\mathrm{v} / \mathrm{v}$ ) for approximately one month at 21 to $25^{\circ} \mathrm{C}$. These colonized kernels are air dried, and then planted simultaneously with seed of the crop to be tested at a rate of $3 \mathrm{~g}$ of inoculum per meter of row. The infected oat kernel inoculum can be stored at $4^{\circ} \mathrm{C}$ and used over a 6-to-9month period without loss of viability.

If naturally-infested soil is available, it can also be used with or without supplementation with conidia.

Disease rating. If disease develops quickly after planting, stand counts can be of value in estimating differences in treatments, especially if noninoculated controls are included. Treatments where the pathogen is functional may give stand reductions of a few percent to as high as $50 \%$. In many cases, however, early season symptoms are not pronounced and disease ratings on older plants are taken. The system best known is that developed by Tinline et al (26), in which the plants are removed from the soil and the subcrown internode rated for disease severity. This system is useful for rating large numbers of plants from the field $(17,19,20,25,26,27)$.

The subcrown internodes are rated for both incidence (percent plants infected) and severity of infection $(2,4,5)$. Grain yield per plant declines with increasing disease severity evaluated by either incidence of infection or severity based on a scale where the plants are placed into one of four classes as follows: Clean, slight, moderate, and severe, which corresponds to 0,1 to $25 \%, 26$ to $50 \%$, and greater than $50 \%$ of the subcrown internode tissue covered by lesions, as illustrated by Ledingham (17) (Fig. 4). Heritability of resistance has been studied by determining the percent severely infected plants with dark brown discoloration and lesions covering $50 \%$ or more of the subcrown internode (16). A weighted average (9) has been used to convert these classes into a percentage. A more simplified version is to merely convert the scores into two classes with clean and slight scored as resistant and moderate, and severe scored as susceptible (19). Using a video camera and computer techniques, image analysis has been used to better quantify the effect of common root rot on the grouth and discoloration of the subcrown internode $(14,15)$.

\section{Literature Cited}

1. Alcorn, J. L. 1983. Generic concepts in Drechslera, Bipolaris, and Exserohilum. Mycotaxon 17:1-86.

2. Bailey, K. L., Harding, H., and Knott, D. R. 1989. Disease progression in wheat lines and cultivars differing in levels of resistance to common root rot. Can. J. Plant Pathol. 11:273-278.

3. Chinn, S. H. F., Sallans, B. J ., and Ledingham, R. J . 1962. Spore populations of Helminthosporium sativum in soils in relation to the occurrence of common root rot of wheat. Can. J. Plant Sci. 42:720-727.

4. Conner, R. L. 1990. Interrelationship of cultivar reactions to common root rot, black point and spot blotch in spring wheat. Plant Dis. 74:224-227.

5. Conner, R. L., and Atkinson, T. G. 1989. Influence of continuous cropping on severity of common root rot in wheat and barley. Can. J . Plant Pathol. 11:127-132. 
6. Dodman, R. L., and Reinke, J . R. 1982. A selective medium for determining the population of viable conidia of Cochliobolus sativus in soil. Aust. J . Agric. Res. 33:287-291.

7. Duczek, L. J. 1989. Relationship between common root rot (Cochliobolus sativus) and tillering in spring wheat. Can. J . Plant Pathol. 11:39-44.

8. Duczek, L. J., Verma, P. R., and Spurr, D. T. 1985. Effect of inoculum density of Cochliobolus sativus on common root rot of wheat and barley. Can. J . Plant Pathol. 7:382-386.

9. Grey, W. E., and Mathre, D. E. 1984. Reaction of spring barleys to common root rot and its effect on yield components. Can. J . Plant Sci. 64:245-253.

10. Harding, H. 1971. Effect of Bipolaris sorokiniana on germination and seedling s survival of varieties or lines of 14 Triticum species. Can. J . Bot. 49:281-287.

11. Harding, H. 1972. Reaction to common root rot of 15 Triticum species and the incidence of Bipolaris sorokiniana and Fusarium spp. in subcrown internode tissue. Can. J . Bot. 50:1805-1810.

12. Harding, H. 1979. Cochliobolus sativus (Ito \& Kurib.) Drechsl. Ex Dastur (Imperfect stage: Bipolaris sorokiniana (Sacc. in Sorok.) Shoem.): A bibliography. Agriculture Canada Research Branch, Saskatoon, Sask. (+ supplements 1-3, 1981, 1983, 1986).

13. Hosford, R. M., Solangi, G. R. M., and Kiesling, R. L. 1975. Inheritance in Cochliobolus sativus. Phytopathology 65:699-703

14. Kokko, E. G., Conner, R. L., Kozub, G. C., and Lee, B. 1993. Quantification by image analysis of subcrown internode discoloration in wheat caused by common root rot. Phytopathology 83:976-981.

15. Kokko, E. G., Conner, R. L., Kozub, G.C., and Lee. B. 1995. Effects of common root rot on discoloration and growth of the spring wheat root system. Phytopathology 85:203-208.

16. Kutcher, H. R., Bailey, K. L. Rossnagel, B. G., and Legge, W. G. 1996. Identification of RAPD markers for common root rot and spot blotch (Cochliobolus sativus) resistance in barley. Genome 39:206-215.

17. Ledingham, R. J., Atkinson, T. G, Horricks, J . S., Mills, J . T., Piening, L. J ., and Tinline, R. D. 1973. Wheat losses due to common root rot in the prairie provinces of Canada, 1969-71. Can. Pl. Dis. Surv. 53:113-122.

18. Piening, L. J . 1997. Common root rot and seedling blight. Pages 10-13 in: Compendium of Barley Diseases. D. E. Mathre, ed. American Phytopathological Society, St. Paul, MN.

19. Piening, L. J ., and Orr, D. 1988. Effects of crop rotation on common root rot of barley. Can. J . Plant Pathol. 10:61-65.

20. Piening, L. J ., Atkinson, T. G., Horricks, J . D., Ledingham, R. J ., Mills, J. T., and Tinline, R. D. 1976. Barley losses due to common root rot in the prairie provinces of Canada, 1970-72. Can. Plant Dis. Surv. 56:41-45.

21. Reis, E. M. 1983. Selective medium for isolating Cochliobolus sativus from soil. Plant Dis. 67:68-70.

22. Specht, L. P., and Rush, C. M. 1988. Fungi associated with root and foot rot of winter wheat and populations of Cochliobolus sativus in the Texas panhandle. Plant Dis. 72:959-963.

23. Stack, R. W. 1977. A simple selective medium for isolation of Cochliobolus sativus from diseased cereal crowns and roots. Plant Dis. Rep. 61:521-522.

24. Stack, R. W. 1980. Disease progression in common root rot of spring wheat and barley. Can. J . Plant Pathol. 2:187-193.

25. Stack, W. R. 1992. Bipolaris. Pages 94-99 in: Methods for Research on Soilborne Pathogenic Fungi. L. L. Singleton, J . D. Mihail, and C. M. Rush, eds. American Phytopathological Society, St. Paul, MN.

26. Tinline, R. D., Ledingham, R. J., and Sallans, B. J . 1975. Appraisal of loss from common rot rot in wheat. Pages 22-26 in: Biology and control of soil-borne plant pathogens. G. W. Bruehl, ed. American Phytopathological Society, St. Paul, MN.

27. Tinline, R. D., Diehl, J . A., and Spurr, D. T. 1994. Assessment methods for evaluating common root rot in spring wheat and infection of subterranean plant parts by the causal fungus Cochliobolus sativus. Can. J . Plant Pathol. 16:207-214.

28. Wiese, M. V. 1987. Common (Dryland) root and foot rot and associated leaf and seedling diseases. Pages 53-55 in: Compendium of Wheat Diseases. American Phytopathological Society, St. Paul, MN. 
Appendix

\section{Czapek's Medium}

$\begin{array}{ll}\mathrm{NaNO}_{3} & 3.0 \mathrm{~g} \\ \mathrm{~K}_{2} \mathrm{HPO}_{4} & 1.0 \mathrm{~g} \\ \mathrm{MgSO}_{4} \cdot 7 \mathrm{H}_{2} \mathrm{O} & 0.5 \mathrm{~g} \\ \mathrm{KCl} & 0.5 \mathrm{~g} \\ \mathrm{FeSO}_{4} 7 \mathrm{H}_{2} \mathrm{O} & 0.01 \mathrm{~g} \\ \text { Sucrose } & 30 \mathrm{~g} \\ \text { Agar } & 15 \mathrm{~g} \\ \mathrm{H}_{2} \mathrm{O} & 1000 \mathrm{ml}\end{array}$

\section{V-8 J uice Medium}

$\begin{array}{ll}\text { V-8 Juice } & 350 \mathrm{ml} \\ \mathrm{CaCO}_{3} & 5 \mathrm{~g}\end{array}$

- Centrifuge at $4000 \mathrm{rpm}$ for $20 \mathrm{~min}$

- Dilute supernatant 1:4 with distilled water

- Add 20 g agar

\section{Glucose Mineral Salts Medium}

$\begin{array}{ll}\mathrm{KNO}_{3} & 3.12 \mathrm{~g} \\ \mathrm{~K}_{2} \mathrm{HPO}_{4} & 750 \mathrm{mg} \\ \mathrm{KH}_{2} \mathrm{PO}_{4} & 750 \mathrm{mg} \\ \mathrm{MgSO}_{4} 7 \mathrm{H}_{2} \mathrm{O} & 500 \mathrm{mg} \\ \mathrm{NaCl} & 100 \mathrm{mg} \\ \mathrm{CaCl}_{2} 2 \mathrm{H}_{2} \mathrm{O} & 100 \mathrm{mg} \\ \mathrm{ZnSO}_{4} 7 \mathrm{H}_{2} \mathrm{O} & 0.396 \mathrm{mg} \\ \mathrm{CuSO}_{4} 5 \mathrm{H}_{2} \mathrm{O} & 0.079 \mathrm{mg} \\ \mathrm{MnSO}_{4} 4 \mathrm{H}_{2} \mathrm{O} & 0.0405 \mathrm{mg} \\ \mathrm{MoO}_{3} & 0.0175 \mathrm{mg} \\ \text { Ferric Citrate } & 0.5355 \mathrm{mg} \\ \mathrm{Glucose}_{\text {Agar }} & 5.0 \mathrm{~g} \\ \mathrm{H}_{2} \mathrm{O} & 20 \mathrm{~g} \\ & 1000 \mathrm{ml}\end{array}$

